\title{
ARNOLD VINCENT MILLER
}

A V Miller was a true scholar. He combined an awesome intellect with an equally awesome modesty, gentleness, humility and humour. He was one of the last Victorians, being 92 when he died and his life spanned most of this century. By virtue of circumstance and his own search for truth through Hegelian philosophy, his life makes a fascinating chronicle of one man's journey through a century of almost unimaginable change in the outer world and the triumph of his own intellectual and spiritual quest.

He was born in 1899, the fourth child in four years, to a poor, but devout, Water Board Inspector and his wife and reared in the rigid doctrines of the Strict and Particular Baptists and the respectable working class. His intelligence showed itself early on by winning him a scholarship to Hilldrop Road County Secondary School in North London, whence he matriculated at sixteen. He was already outgrowing the dogma of the Baptist and began his philosophical quest by flirting with Theosophy before being called up to the Rifle Brigade in March 1917. After a year's training he arrived in the trenches of N E France in March 1918. His experience of trench warfare must be one of the shortest in history. No sooner had Arnold dug his hole on the first morning in action than Jerry appeared out of the mist and promptly made him a prisoner of war.

Because of his knowledge of German and French he was moved to a German military hospital at Charleville - Mézières where he spent the rest of the war as a theatre orderly. There, he experienced all the horrors of a World War One operating theatre, as well as malnutrition, dysentery and lice.

Somehow, amongst the degradation and carnage, a close-knit cosmopolitan community of priests, nuns, doctors, nurses, captors and captives sustained and supported each other through their common humanity and their search for mutual understanding. What a breeding ground for philosophy that must have been.

Following his demobilisation and fruitless attempts to find work, Arnold volunteered to go to Vienna with the Quakers and distribute food to the starving children. He travelled on the first post-war Orient Express to cross war-torn Europe and arrived in Vienna in 1920. It was there that he developed communist leanings, had a great deal of fun, and with his dolichocephalic head, Roman nose, shock of wild, wavy red hair, laid back manner and insatiable appetite for debating the eternal verities, he anticipated the hippie life by forty years.

Back in London, in the 20s, and still unemployed, he was drawn irresistibly to the soap boxes of Hyde Park Corner. Turned out of the Park at midnight, he and a fellow soap box orator would spend the rest of the night pacing the miles, back and forth across 
London between their respective homes in Chiswick and Islington - still in earnest debate. It was this same Chiswick chemist who directed Amold to Whiteway, a small commune on the Cotswolds, where he met Francis Sedlak, a Czech refugee and Hegelian philosopher, whose disciple and friend he became.

This meeting marked the crossroads in his life. By the late Twenties his outer life had become conventional and his remarkable inner journey into Philosophy had begun. He became a civil servant, married his beloved Francesca and eventually sired two dughters during World War Two. In Hegel he had finally identified his Pole Star and from that moment he left the external world to take care of itself and followed Hegel with unfaltering steps.

World War Two diverted his attention only temporarily with the nightmare of commuting to London by day, air raid warden duty by night, and rearing two babies in an air raid shelter. With the war over he spent most evenings after work steeping himself in Hegel. Alone and completely self taught, untutored by any formal academic structure, he struggled to grasp Hegel's great dialectic "through which the individual soul finds itself on a new elevation and with new powers".

His by now considerable knowledge of German soon enabled him to realise that the only English translations of Hegel were but vapid shadows of the original. They were frequently inaccurate and a travesty of the Master's work. Tentatively, he began to experiment with his own translations, the better to test his understanding and make good the deficiencies.

Meanwhile, mainstream philosophy was travelling another road - and in the opposite direction. Neo-Hegelianism had long since been relegated to some dusty cupboard of the late nineteenth and early twentieth centuries with the publication in 1936 of Language Truth and Logic. By the 1940s Logical positivism was the order of the day and philosophy identified itself almost exclusively with mathematics and the natural sciences. There is nothing so sweet to those seeking to establish an ideology as a common enemy, and so Hegel became an anathema and was castigated as the evil genius behind totalitarian continental philosophy. Arnold's unorthodox Hegelian voice had yet to be heard but there was to be one lone voice which would herald him, from within the establishment pale, and without whom Amold's voice would never have been heard. That voice belonged to John Findlay, Professor of Philosophy at London University. In 1958 he published Hegel - $a$ Reexamination and the academic world sat up and took notice.

Findlay approached Hegel neither as Communist, Theologian nor Natural Scientist, but as a Phenomenologist. While Logical positivism held sway, those like Findlay, who specialised in Hegel, were themselves in a philosophical backwater. Findlay was no exception, but his book marked a watershed and the tide imperceptibly turned. 
Arnold suspected that in Findlay he might find, if not a kindred spirit, a sympathetic colleague, as proved to be the case. In the late $1950 \mathrm{~s}$, shortly before his retirement, he submitted samples of his translation to Findlay, who immediately recognised the quality of his scholarship and invited him to an introductory meeting. The years of isolation were over.

With Findlay's backing, the longer Logic was published in 1969 to unanimous international acclaim. He spent the next 17 years translating and publishing most of Hegel's major works, six volumes in all, the Logic alone comprising more than 800 pages. He attended Hegelian conferences and seminars both in the UK and the US up until six months before his death when he was rising 92 . Undaunted by his lack of formal education, he tackled Higher Mathematics, Physics, Chemistry and the Greek Philosophers. He seemed to inhabit Hegel's mind as though it were his own and the very fabric of his being. A V Miller brought Hegel to the English speaking world and made his work available to anyone who could read and had the tenacity to stretch the mind and spirit to a formidable level. Hegel is no easy taskmaster.

Of course, the longer Logic and the Phenomenology are of special interest to Hegelians because they are seen to contain his basic methodology. Arnold, however, considered the Logic alone to be Hegel's masterpiece and the Phenomenology an optional extra, to the point where he resisted for several years all demands to translate it. For him, the specialised fields of the Philosophy of Nature and the Philosophy of the Subjective Spirit were of overriding importance and led him to the very heart and essence of Hegel, despite the fact that these long and complicated works were ignored by more orthodox Hegelians.

But it was Frances, on the home front, ever Amold's bridge to the external world, who issued the ultimate spiritual challenge. Faced with rearing two daughters in the post World War Two era, she demanded to know the relevance of Hegel to the spiritual development of their children. Amold reflected and found Hegel and Christianity to be essentially sympathetic. In 1946 he was baptised, along with Ann and Mary, and almost immediately confirmed into the Church of England. Church membership became a focus of family life and Amold regularly read the lesson, doing more than a little justice to the effortless prose and understanding of the Authorised Version of the Bible.

Philosophy to Arnold was no mere intellectual exercise but a living, breathing organism. He brought this unshakeable conviction, alongside his astounding scholarship, into the halls of Academia. By translating in his beautiful, lucid manner he presented Hegelians with a challenge in informed, modern English. His quiet presence, modesty and disarming, unaffected humour, justly earned him the love and respect of all who knew him and he became something of a legend in his lifetime. 
The experiences of a World War One German military hospital scarred him for life. As children we grew up with the horror stories of that time. But, because he told of unspeakable things, as though they were just everyday events and tacitly disclaimed the impact that they surely must have had, we, too, accepted the starvation, dysentery, crude amputations, limbs mixed up in coffins, blood, butchery and pain as just something that had happened.

He was not in a hospital again until his 89th year, and it was only then that he relived those earlier experiences, with all the anguish of an 18 year old boy, utterly unequipped for such indecencies and with tears running unchecked down his cheeks. The tears flowed down our cheeks too and we realised, at last, that he like so many, had carried those wounds to the heart and the spirit for more than 70 years.

It was perhaps why, when not engrossed in Hegel, he turned so often to laughter and light entertainment, to anything that was comfortable and not disturbing. In retrospect, much of his life may well have been the flight from too much pain, endured too young; unhealed, because it was never acknowledged or validated. Perhaps, too, it was why he was so passionately committed to mind and spirit. What men do is too terrible to contemplate.

Arnold was wise, too, in his choice of partner, for his Frances supplied all the practical applications of intelligence which he so obstinately abjured. Frances and Arnold, or "Frarnold" as they were affectionately known, were a family firm. He relied on her totally to pay the bills and provide all his creature comforts and the means of survival. Without "Frarnold" there would have been no A V Miller, Hegelian philosopher and transiator.

As father and friend, he was a rare gift. But, he, wise man though he was, was blessed with his fair share of human folly. He could never resist an invitation to play, or discourse, or tell stories, but he could be difficult to live with. His exasperating refusal to address the molehills of day to day living could effectively offset the unswerving vision of the Mountains of Truth, Reason and Wisdom where his towering intellect and humility had their proper home. He was no mean pianist and could harmonise any tune by ear and the old music hall songs like "Nellie Dean" and "Lily of Laguna" were an integral part of life with the Millers. He was a genial man, entertaining and a natural wit. The family home was always open to an ever-increasing circle of friends. Nearly a hundred people gathered to celebrate his eightieth and then his ninetieth birthday.

It was easy to think that he might delay the act of "perfect restoration" to his divine nature for ever. But the last two years witnessed a gradual but progressive weariness. He had only one ambition left; to write his own major work. It was not to be. His genius lay in translating and illuminating the work of his master, Hegel. Amold was surely the man of whom it was written: 
Before the living spirit which indwells a philosophy can be revealed, it must be brought to birth by a kindred spirit.

It was both a joy and a grief to see Arnold receive the acclaim of the Hegelian world with such naive and delighted surprise. He was utterly without hubris or the intellectual arrogance that is so often endemic to academic life. Perhaps his was, after all, the better part, spared the petty jealousies of the intellectual elite - for he remained outside the system to the end. The acclaim was never substantiated or officially recognised by the accolade of an honorary degree. No university ever welcomed him into its fold. It never occurred to him that they should - he was blissfully unaware of such worldly trappings. But to his family and friends and doubtless to many students, lecturers and professors who owe him so much, a tribute to that mammoth contribution of solid and inspired scholarship should have been made.

His death was unhurried, a joyous celebration and affirmation of a life complete. We who knew him loved him and we honour his greatness - the man and his work.

Mary Lettington

Amold Vincent Miller, Hegelian philosopher and translator, born London 10 January 1899, published translations of Hegel: Science of Logic 1969, Philosophy of Nature, 1970, Philosophy of Mind 1971, Phenomenology of Spirit, 1977, Introduction to Lectures of History of Philosophy 1985, (collab). Philosophic Propadeutic 1986. Married 1933 Frances Reeve, (two daughters), died Cirencester 19 March 1991. 